\title{
Chemotactic Peptide Activation of Human Neutrophils and HL-60 Cells \\ Pertussis Toxin Reveals Correlation between Inositol Trisphosphate Generation, Calcium Ion Transients, and Cellular Activation
}

\author{
Karl-Heinz Krause, Werner Schlegel, Claes B. Wollheim, Tommy Andersson, Francis A. Waldvogel, and P. Daniel Lew \\ Division des maladies infectieuses, Hopital Cantonal Universitaire, Fondation pour recherches medicales; Institut de biochemie clinique, \\ Centre Medical Universitaire, Geneva, Switzerland; Department of Medical Microbiology, University of Linköping, Sweden
}

\begin{abstract}
The mechanism of neutrophil activation by the chemotactic peptide formyl-methionyl-leucyl-phenylalanine (FMLP) has been studied by pretreatment of human neutrophils with pertussis toxin. Upon stimulation with FMLP, the cytosolic-free calcium concentration, $\left[\mathrm{Ca}^{2+}\right]$, is increased both by stimulation of calcium influx and mobilization of cellular calcium. We have measured $\left[\mathrm{Ca}^{2+}\right]_{\text {as }}$ well as the generation of the phospholipid breakdown product inositol trisphosphate (IP $\left.{ }_{3}\right)$, which is thought to mediate $\mathrm{Ca}^{2+}$ mobilization. As the phosphoinositide pool in human neutrophils is difficult to prelabel with $\left.{ }^{3} \mathrm{H}\right]$ myoinositol, experiments were also carried out in the cultured human promyelocytic leukemia cell line HL-60 after differentiation with dimethylsulf-
\end{abstract} oxide.

Pertussis toxin pretreatment of both cell types inhibited FMLP stimulated membrane depolarization, exocytosis, and superoxide production in a dose-dependent manner. This toxin effect was selective for the receptor agonist, since stimulation of these parameters by two substances bypassing the transduction mechanism, the calcium ionophore ionomycin and the phorbolester phorbol myristate acetate, were unaffected.

Rises in $\left[\mathrm{Ca}^{2+}\right]_{1}$, as well as generation of $\mathrm{IP}_{3}$ in response to FMLP, were inhibited in parallel; for the inhibition of functional responses, slightly lower toxin concentrations were required. The attentuation of the $\left[\mathrm{Ca}^{2+}\right]_{1}$ rise was more marked in the absence of extracellular calcium, i.e., when the rise is due only to calcium mobilization.

The results provide evidence that phospholipase $\mathbf{C}$ stimulation by FMLP resulting in $\mathrm{IP}_{3}$ generation is involved in the signal transduction mechanism. Coupling of FMLP receptor occupancy to phospholipase $C$ activation is sensitive to pertussis toxin, suggesting the involvement of a GTP binding protein ( $N$ protein), which has been shown to be a pertussis toxin substrate. The parallel changes in $\left.\mathrm{Ca}^{2+}\right]$ and $\mathrm{IP}_{3}$ further support the hypothesis that $\mathrm{IP}_{3}$ is the calcium-mobilizing mediator in FMLPactivated cells.

Dr. Krause is a recipient of a fellowship of the Paul-Martini-Stiftung. Dr. Lew is a recipient of a Max Cloetta Career Development award. Dr. Andersson is a recipient of a postdoctoral fellowship from the Swedish Society of Medicine: Address reprint requests to Dr. Krause, Hopital Cantonal Universitaire.

Received for publication 3 May 1985.

J. Clin. Invest.

(c) The American Society for Clinical Investigation, Inc.

$0021-9738 / 85 / 10 / 1348 / 07 \quad \$ 1.00$

Volume 76, October 1985, 1348-1354

\section{Introduction}

The interaction of the chemotactic peptide formyl-methionylleucyl-phenylalanin (FMLP) ${ }^{1}$ with specific cell surface receptors in neutrophils leads to a rapid rise in cytosolic-free calcium $\left(\left[\mathrm{Ca}^{2+}\right]_{i}\right)$, which appears to be necessary for cellular activation $(1,2)$. Two recent observations suggest that inositol trisphosphate $\left(\mathrm{IP}_{3}\right)$, a product of the hydrolysis of the plasma membrane phospholipid phosphatidylinositol 4,5-bisphosphate ( PIP $_{2}$ ) by phospholipase $\mathrm{C}$ (also referred to as polyphosphoinositide phosphodiesterase), acts as a second messenger: $\mathrm{IP}_{3}$ is generated within seconds after chemotactic peptide stimulation of neutrophils $(3,4)$ and HL-60 cells $(5)$ without the need for a previous rise in $\left[\mathrm{Ca}^{2+}\right]_{i}(3)$; $\mathrm{IP}_{3}$ releases $\mathrm{Ca}^{2+}$ from intracellular stores in neutrophils permeabilized by digitonin treatment (6).

It remains, however, unclear how the stimulus receptor complex activates phospholipase $C$. Recent data in several systems suggest the involvement of nucleotide regulatory proteins, called $N$ proteins (7) or $G$ proteins (8), in receptor stimulation of PIP ${ }_{2}$ breakdown (9-11). Bacterial toxins, namely cholera toxin and pertussis toxin, have been used in the past to investigate the role of $\mathrm{N}$ proteins in receptor coupling, since they modify $\mathrm{N}$ protein function by ADP ribosylation (8). Pertussis toxin has been shown to impair the function of the inhibitory $\mathrm{N}$ protein linked to adenylate cyclase, $N_{i}(12,13)$, and more recently it has been suggested that pertussis toxin may interfere with receptor-mediated alterations of phospholipid metabolism. In neutrophils, it has been shown that pertussis toxin interacts with the FMLP-induced rise in $\left[\mathrm{Ca}^{2+}\right]_{i}(14)$ and alters the transient decrease in $\mathrm{PIP}_{2}$ assessed by short-term labeling with ${ }^{32} \mathrm{P}$ $(15,16)$.

In the present study we directly measured the generation of the putative second messenger $\mathrm{IP}_{3}$ after long-term labeling of the phosphoinositides in human neutrophils and in the differentiated human promyelocytic leukemic cell line HL-60. Our results demonstrate that pertussis toxin blocks the FMLP-induced rise in $\mathrm{IP}_{3}$ in both cell types, and provide substantial evidence for the involvement of a pertussis toxin substrate, presumably a $\mathrm{N}$ protein, in the coupling of FMLP receptors to the stimulation of phospholipase $\mathrm{C}$ in two cell types. The concom-

1. Abbreviations used in this paper: $\left[\mathrm{Ca}^{2+}\right]_{\mathrm{i}}$, cytosolic-free calcium; $\mathrm{Di}-\mathrm{O}-\mathrm{C}_{5}(3)$, 3-3'dipentyloxacarbocyanine; DMSO, dimethylsulfoxide; FMLP, formyl-methionyl-leucyl-phenylalanin; GTP, guanosin-triphosphate; $\mathbf{I P}_{1}$, inositol phosphate; $\mathbf{I P}_{2}$, inositol bisphosphate; $\mathbf{I P}_{3}$, inositol trisphosphate; PI, phosphatidylinositol; PIP $_{1}$, phosphatidylinositol; PIP $_{2}$, phosphatidylinositol 4,5-bisphosphate; PMA, phorbol myristate acetate; quin2/AM, quin 2 acetoxy-methylester. 
itant inhibition by pertussis toxin of a rise in $\left[\mathrm{Ca}^{2+}\right]_{i}$ and several functional responses to FMLP but not to receptor independent stimulation allowed the assessment of receptor-stimulated $\mathrm{IP}_{3}$ production in neutrophil activation.

\section{Methods}

The materials and their sources were as follows: pertussis toxin (List Biological Laboratories Inc., Campbell, CA), FMLP, phorbol myristate acetate (PMA), cytochalasin B, cytochrome $c$ (Sigma Chemical Co., St. Louis, MO), myo- $\left(2-{ }^{3} \mathrm{H}\right)$ inositol and quin2 acetoxy-methylesther (quin2/ AM) (Amersham Int'l. plc, Amersham, England), and Dextran T500 and Ficoll Hypaque (Pharmacia Fine Chemicals, Upsala, Sweden). 33'dipentyloxacarbo-cyanine iodide, Di-O-C 5 (3) (Molecular Probes Inc., Junction City, OR), and 4-methylumbelliferyl substrates were from Koch Laboratories, Haverhill, England. Ionomycin was a kind gift of Dr. C. M. Liu of Hoffmann-La Roche, Inc., Nutley, NJ.

Preparation of human neutrophils. Neutrophils were prepared from fresh blood samples (usually $90 \mathrm{ml}$ ) obtained from healthy volunteers. Fresh neutrophils were purified by dextran sedimentation followed by centrifugation through a layer of Ficoll as described previously $(17,18)$. The cells were suspended in a medium containing $138 \mathrm{mM} \mathrm{NaCl}, 6 \mathrm{mM}$

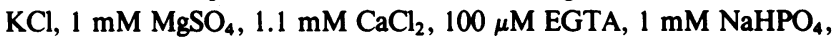
$5 \mathrm{mM} \mathrm{NaHCO}$, $5.5 \mathrm{mM}$ glucose, and $20 \mathrm{mM}$ Hepes, $\mathrm{pH} 7.4$ (This medium will be referred to as calcium medium; calcium-free medium will refer to the above medium without $\mathrm{CaCl}_{2}$, supplemented with 1 mM EGTA).

Culture of HL-60 cells. The cells were cultured in RPMI-1640 medium supplemented with $10 \%$ heat-inactivated fetal calf serum, penicillin $(100 \mathrm{U} / \mathrm{ml})$, and streptomycin $(100 \mu \mathrm{g} / \mathrm{ml})$. The cells were passaged once every week, and only cells with passage number below 35 were used for the experiments. Differentiation of the cells was induced by adding dimethylsulfoxide (DMSO) (final concentration 1.3\%, vol/vol) to the cell suspension. Cells were used for all experiments after $4 \mathrm{~d}$ of differentiation.

Preparation of cells for labeling experiments. Phosphoinositides and inositol phosphates were labeled by incubating cells in RPMI medium containing myo- $\left(2-{ }^{3} \mathrm{H}\right)$ inositol $(1 \mu \mathrm{Ci} / \mathrm{ml})$ and 10 and $3 \%$ heat-inactivated serum, respectively, for HL-60 cells and human neutrophils. HL-60 cells were incubated under these conditions for $48 \mathrm{~h}$ and human neutrophils for $18 \mathrm{~h}$, as described $(3,5)$.

Incubation with pertussis toxin. $50 \mu \mathrm{g}$ of pertussis toxin were diluted in $500 \mu$ l of a buffer containing $0.1 \mathrm{M}$ sodium phosphate, $\mathrm{pH} 7.0$, and $0.5 \mathrm{M} \mathrm{NaCl}$, yielding a stock concentration of $100 \mu \mathrm{g} / \mathrm{ml}$. Cells were suspended in calcium medium at a concentration of $10^{7}$ cells $/ \mathrm{ml}$ and incubated for $2 \mathrm{~h}$ at $37^{\circ} \mathrm{C}$ with the respective concentration of pertussis toxin. Control cells were incubated with the equal amount of buffer.

Measurement of cytosolic-free calcium. Quin2 loading, fluorescent measurement, and calibration were performed as described previously (1).

Degranulation. $1.25 \times 10^{6}$ cells were suspended in $500 \mu \mathrm{l}$ of calcium medium containing $2.5 \mu \mathrm{g}$ cytochalasin B and warmed at $37^{\circ} \mathrm{C}$ for 5 $\mathrm{min}$ before addition of stimuli at the indicated concentration and time. Incubation was terminated by rapid cooling in ice and centrifugation $(800 \mathrm{~g}$ for $10 \mathrm{~min})$. Enzymes and vitamin $\mathrm{B}_{12}$-binding protein were assayed in the supernatants and calculated as a percentage of control cells (cells incubated without pertussis toxin). For control cells, percentage of total cell protein released from an aliquot of the same cell suspension treated with $0.025 \%$ Triton $\mathrm{X}-100$ for $5 \mathrm{~min}$ at $37^{\circ} \mathrm{C}$ is shown in the figure legend.

$\beta$-glucuronidase and $N$-acetyl- $\beta$-glucosaminidase were measured fluorimetrically with 4-methylumbelliferyl substrates (19). The unsaturated vitamin $B_{12}$-binding protein was assayed by a slight modification of the method of Kane et al. (19).

Superoxide production. Superoxide production was monitored continuously in a double beam spectrophotometer, thermostated at $37^{\circ} \mathrm{C}$ as previously described (20). Data are shown as percentage of control cells (cells not treated with pertussis toxin). For control cells, absolute values are given in the figure legend.

Depolarization. Changes in membrane potential were measured by a flourimetric assay, using the membrane potential-sensitive Cyanine Dye Di-O-C $\mathrm{C}_{5}(3)$ as described by Seligman (21). A Perkin-Elmer fluorimeter was used. Excitation and emission wavelength were $460 \mathrm{~nm}$ and $520 \mathrm{~nm}$, respectively. Di- $O-\mathrm{C}_{5}(3)$ was added to a final concentration of $10^{-7} \mathrm{M}$ and cells were added to a final concentration of $5 \times 10^{5}$ cells/ $\mathrm{ml}$. The temperature of the cuvette was maintained at $37^{\circ} \mathrm{C}$ and the suspension was magnetically stirred. Fluorescence changes are reported as a percentage of the maximal fluorescence, taking the fluorescence of $\mathrm{Di}-\mathrm{O}-\mathrm{C}_{5}(3)$ without cells as $0 \%$ and the fluorescence after the addition of nonstimulated cells (equal maximal fluorescence) as $100 \%$.

Measurement of phosphoinositides and inositolphosphates. For the determination of stimulus-induced changes in phosphoinositides and inositol phosphates the prelabeled cells were washed by suspending twice at $37^{\circ} \mathrm{C}$ for $10 \mathrm{~min}$ in RPMI medium without inositol. The cells were resuspended in calcium medium and incubated for $2 \mathrm{~h}$ with or without pertussis toxin. The cells were finally resuspended in calcium medium, warmed for $5 \mathrm{~min}$ at $37^{\circ} \mathrm{C}$, followed by the addition of various stimuli for the indicated time; control cells were treated in parallel with appropriate solutions. For experiments with human neutrophils and HL-60 cells, the number of cells used for each incubation condition was, respectively, $12 \times 10^{6}$ cells and $3 \times 10^{6}$ cells. Preincubation of HL-60 cells with lithium $\left(10 \mathrm{mM} \mathrm{LiCl}_{2}\right.$ for $10 \mathrm{~min}$ at $\left.37^{\circ} \mathrm{C}\right)$ in some experiments did not alter basal or stimulated $\mathrm{IP}_{3}$ levels. Therefore, all our experiments reported here were performed in its absence.

Incubations were terminated by addition of $10 \%$ (vol/vol) trichloroacetic acid. The samples were kept on ice 5-10 min and centrifuged. The phospholipids in the trichloroacetic acid precipitate were extracted with $5.5 \mathrm{ml}$ of chloroform/methanol/HCl, $12 \mathrm{~N}$ (2:1:0.0075), the extracts washed three times with $1 \mathrm{ml}$ of chloroform/methanol/HCl, $0.6 \mathrm{~N}$ (3:48:47), and dried under a stream of air. Phosphoinositides were analyzed by thin-layer chromatography according to Jolles et al. (22).

The supernatant was washed three times with a fivefold excess of diethylether. The washed extract was adjusted to $\mathrm{pH} 7.5$ with Tris 0.2 $M$ and inositol phosphates separated by stepwise elution from Dowex (formate) columns as described (23). Radioactivity in the fractions was determined by liquid scintillation counting with $67 \%$ (vol/vol) aquasol. The inositol trisphosphate fraction may have included both the active calcium-mobilizing isomer $1,4,5$ and the isomer $1,3,4$. No attempt has been performed to distinguish between these two possibilities.

\section{Results}

\section{Human neutrophils}

Functional studies. Because of quantitative differences of the effects of pertussis toxin on neutrophils from different donors, the results presented here were all obtained from cells of the same donor in order to allow quantitative correlation among various functions. All parameters were qualitatively reproduced in cells from two additional donors.

In Fig. 1 is shown the effect of preincubation of human neutrophils for $2 \mathrm{~h}$ at $37^{\circ} \mathrm{C}$ with various concentrations of pertussis toxin on degranulation of secondary granules upon stimulation with the chemotactic peptide FMLP $(1 \mu \mathrm{M})$, the calcium ionophore ionomycin (250 $\mathrm{nM})$, and the phorbol ester PMA (100 $\mathrm{nM}$ ), as assessed by release of vitamin $\mathrm{B}_{12}$ binding protein. The response to ionomycin and PMA, which bypass cell surface receptors, is unaltered, whereas the response to FMLP is inhibited in a dose-dependent manner.

FMLP-induced degranulation of primary granules, as assessed in the same supernatants by the release of $\beta$-glucuronidase, was $44 \% \pm 2,5 \pm 5 \%$, and $2 \pm 5 \%$ of control (without pertussis toxin) 


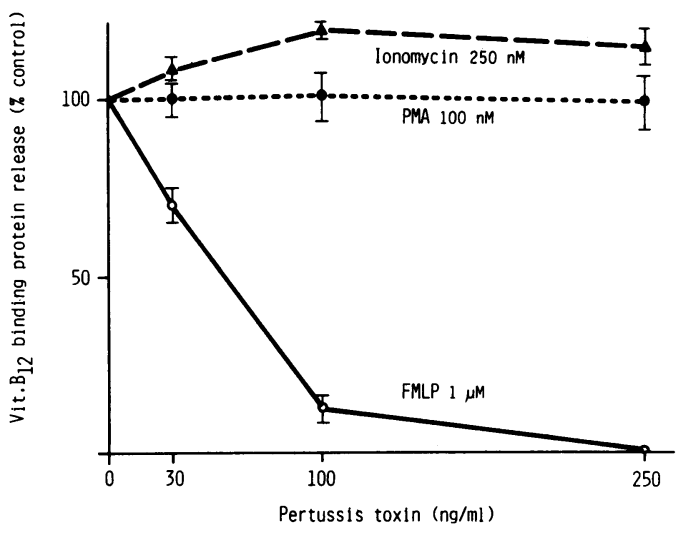

Figure 1. Effect of increasing concentrations of pertussis toxin on vitamin $B_{12}$ binding protein release after 5 min incubation with $1 \mu \mathrm{M}$ FMLP, $250 \mathrm{nM}$ ionomycin, and $100 \mathrm{nM}$ PMA in human neutrophils. Results are expressed as percentage of control cells (cells incubated without pertussis toxin). Control cells released $39 \pm 1.8 \%$ (FMLP), $63 \pm 1.9 \%$ (ionomycin), and $49 \pm 1.5 \%$ (PMA) of their total vitamin $B_{12}$ binding protein content (after subtraction of basal values). Results are mean \pm SD of 3-6 determinations.

values after preincubation with 30,100 , and $250 \mathrm{ng} / \mathrm{ml}$ of pertussis toxin, respectively.

FMLP-induced superoxide production was $9 \pm 9 \%$ of control (without pertussis toxin) values after preincubation with $30 \mathrm{ng} /$ $\mathrm{ml}$, and was completely abolished after preincubation with 100 and $250 \mathrm{ng} / \mathrm{ml}$ of pertussis toxin.

Changes in the average membrane potential of human neutrophils were assessed with the fluorescent probe $\mathrm{Di}-\mathrm{O}-\mathrm{C}_{5}(3)(21)$. As is shown in Fig. 2, neutrophils are depolarized by FMLP (panel $A$ ), ionomycin (panel $B$ ), and PMA (panel $C$ ). Pertussis toxin treatment suppresses in a dose-dependent manner the response to FMLP, while the depolarization induced by PMA or ionomycin are unaffected.

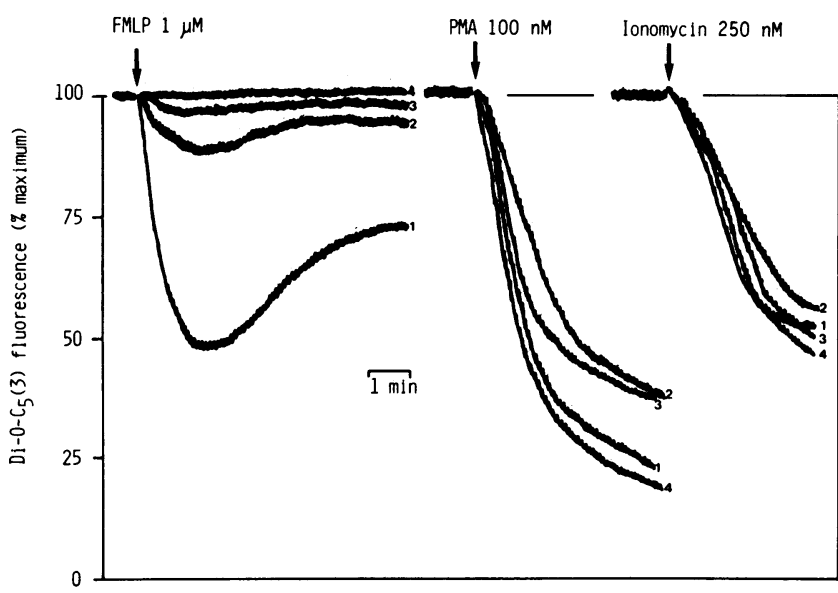

Figure 2. Effect of increasing concentrations of pertussis toxin on depolarization of human neutrophils after the addition of $1 \mu \mathrm{M}$ FMLP $(A), 100 \mathrm{nM}$ PMA $(B)$, and $250 \mathrm{nM}$ ionomycin $(C)$. The scale to the left shows percentage of maximal fluorescence (medium plus $\mathrm{Di}-O$ $\mathrm{C}_{5}(3)=0 \%$; medium plus $\mathrm{Di}-\mathrm{O}-\mathrm{C}_{5}(3)$ plus unstimulated cells $=100 \%)$. Traces (1), (2), (3), and (4) are done with neutrophils preincubated with $0,30,100$, and $250 \mathrm{ng} / \mathrm{ml}$ pertussis toxin, respectively. Traces are representative of 3-6 experiments.

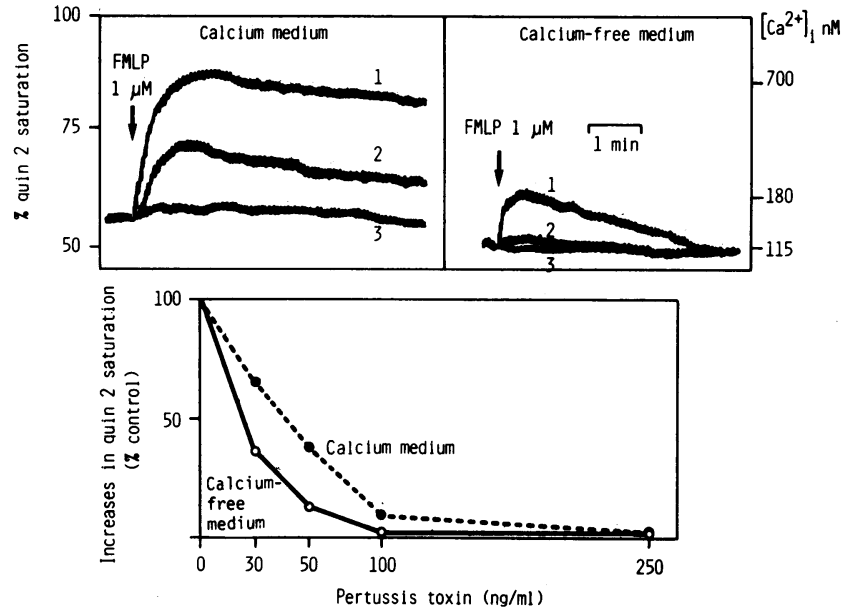

Figure 3. $(A)$ Quin2 traces recorded from human neutrophils in calcium medium (left) and calcium-free medium (right), in cells preincubated without (1), with $30(2)$, and $100(3) \mathrm{ng} / \mathrm{ml}$ pertussis toxin. Traces typical for at least three other experiments. $(B)$ Effect of increasing concentrations of pertussis toxin on $\left[\mathrm{Ca}^{2+}\right]_{i}$ in human neutrophils after stimulation with $1 \mu \mathrm{M}$ FMLP in calcium and calcium-free medium. Values are given as percentage of quin2 changes of control cells (same experiment as Fig. $4 \mathrm{~A}$ ).

Intracellular signals. Human neutrophils loaded with the fluorescent calcium indicator quin2 were used to assess the FMLP-induced calcium transients in neutrophils preincubated with increasing concentrations of pertussis toxin. In calcium containing medium the calcium transients are inhibited by increasing concentrations of pertussis toxin. To elucidate, whether this inhibition is due to an effect on calcium influx or mobilization from cellular stores, the experiments were repeated in calcium-free medium. In the latter condition, $\left[\mathrm{Ca}^{2+}\right]_{\mathrm{i}}$ rises reflect release from internal stores, since calcium influx is negligible. In calcium-free medium, the FMLP effect was attenuated at lower pertussis toxin concentrations than in the presence of calcium (Fig. 3). In contrast, the rises in $\left[\mathrm{Ca}^{2+}\right]_{i}$ induced by the calcium ionophore ionomycin, which equilibrates $\mathrm{Ca}^{2+}$ along the electrochemical gradients, were unaffected by pretreatment of cells with pertussis toxin (data not shown).

Extensive experimental evidence indicates that $\mathrm{IP}_{3}$ is a second messenger, which exerts its action by releasing calcium from internal stores in a wide variety of cells, including phagocytes $(6,24,25)$. We therefore measured the production of $\mathrm{IP}_{3}$ and its products of degradation inositol bisphophate $\left(\mathrm{IP}_{2}\right)$ and inositol monophosphate $\left(\mathrm{IP}_{1}\right)$, upon stimulation with $1 \mu \mathrm{M}$ FMLP in cells incubated without and with a maximally inhibitory dose of pertussis toxin $(250 \mathrm{ng} / \mathrm{ml})$. As $\mathrm{IP}_{3}$ is generated from the phospholipid $\mathrm{PIP}_{2}$, and changes in the level of this phospholipid might be an important reason for changes in the receptor-mediated production of $\mathrm{IP}_{3}$, we also measured the levels of $\mathrm{PIP}_{2}$ and its precursors phosphatidylinositol 4-phosphate $\left(\mathrm{PIP}_{1}\right)$ and phosphatidylinositol (PI). In Table I is shown the effect of pertussis-toxin on inositol phosphates and phosphoinositides in neutrophils stimulated with $1 \mu \mathrm{M}$ FMLP for $20 \mathrm{~s}$. A doubling of the production of inositol-phosphates $\left(\mathrm{IP}_{3}, \mathrm{IP}_{2}, \mathrm{IP}_{1}\right)$ is observed after stimulation. This rise is completely inhibited by the preincubation of the cells with pertussis toxin. No major changes due to pertussis toxin or FMLP are seen in the levels of the phosphoinositides. 
Table I. Effect of Pertussis Toxin $(250 \mathrm{ng} / \mathrm{ml})$

on Levels of Inositolphosphates and Phosphoinositides in Human Neutrophils after Stimulation with FMLP

\begin{tabular}{lll}
\hline & Pertussis toxin \\
& $n g / m l$ & $n g / m l$ \\
& 0 & 250 \\
$\mathrm{IP}_{3}$ & $269 \pm 16$ & $110 \pm 3$ \\
$\mathrm{IP}_{2}$ & $183 \pm 10$ & $99 \pm 5$ \\
$\mathrm{IP}_{1}$ & $215 \pm 15$ & $103 \pm 3$ \\
$\mathrm{PIP}$ & $113 \pm 18$ & $105 \pm 14$ \\
$\mathrm{PIP}$ & $128 \pm 18$ & $142 \pm 11$ \\
$\mathrm{PI}$ & $102 \pm 9$ & $113 \pm 3$ \\
\hline
\end{tabular}

Neutrophils were cultured in the presence of myo- $\left[2-{ }^{3} \mathrm{H}\right]$ inositol $(1$ $\mu \mathrm{Ci} / \mathrm{ml}$ ) for $18 \mathrm{~h}$ and with pertussis toxin $250 \mathrm{ng} / \mathrm{ml}$ for $2 \mathrm{~h} .1 \mu \mathrm{M}$ FMLP was added. The reaction was stopped after $20 \mathrm{~s}$ by adding trichloracetic acid. Inositolphosphates were determined in the supernatant, and phosphoinositides in the precipitate. The values are given as percentage of basal values of control cells (cells incubated without pertussis toxin). Basal values of control cells were $66 \pm 4,70 \pm 5$, and $104 \pm 4 \mathrm{dpm}$ for $\mathrm{IP}_{3}, \mathrm{IP}_{2}$, and $\mathrm{IP}_{1}$, respectively, and $229 \pm 9,449 \pm 26$, and $4131 \pm 30 \mathrm{dpm}$ for PIP $_{2}$, PIP $_{1}$, and PI, respectively. Values are mean $\pm \mathrm{SD}$ of three determinations.

\section{$H L-60$ cells}

In order to be able to correlate the effect of pertussis toxin on functional results with the effect on intracellular signals, the functional studies with HL-60 cells were always carried out on the same day with the same batch of cells as studies of inositolphosphates and phosphoinositides. The extent of inhibition of the different parameters by any dose of pertussis toxin did-in contrast to human neutrophils-not vary between different batches of HL-60 cells, reflecting the properties of a homogenous cell line.

Functional studies. As differentiated HL-60 cells do not possess secondary granules, only the degranulation of primary granules was determined, as assessed by the release of glucosaminidase (26). Although the amount of granule content released is substantially lower than in human neutrophils, similar results are observed, i.e., degranulation induced by $250 \mathrm{nM}$ ionomycin is not impaired by increasing concentrations of pertussis toxin, whereas the degranulation induced by $1 \mu \mathrm{M}$ FMLP is almost completely abolished in a dose dependent manner (Fig. $4 \mathrm{~A}$ ). Superoxide production in HL-60 cells in response to $100 \mathrm{nM}$ PMA is unchanged by increasing concentrations of pertussis toxin, whereas superoxide production in response to $1 \mu \mathrm{M}$ FMLP is markedly reduced at $30 \mathrm{ng} / \mathrm{ml}$ and is completely abolished at 100 and $250 \mathrm{ng} / \mathrm{ml}$ (Fig. 4 B).

Intracellular signals. In Fig. 5, left panel, the effects of pertussis toxin on $\mathrm{IP}_{3}$ levels in differentiated HL-60 cells before and $30 \mathrm{~s}$ after stimulation with $1 \mu \mathrm{M}$ FMLP are shown. $\mathrm{IP}_{3}$ levels reach $318 \pm 16 \%$ upon stimulation in control cells. This response is inhibited by pertussis toxin in a dose-dependent manner, such that in cells preincubated with $250 \mathrm{ng} / \mathrm{ml}$ of pertussis toxin, stimulated $\mathrm{IP}_{3}$ levels are only $112 \pm 5 \%$ of unstimulated control cells. In parallel, there is a gradual decline of basal $\mathrm{IP}_{3}$ values from $100 \pm 5 \%$ to $79 \pm 6 \%$ after preincubation of cells with the maximal dose of pertussis toxin.

Fig. 5, left panel, shows changes in FMLP-induced calcium

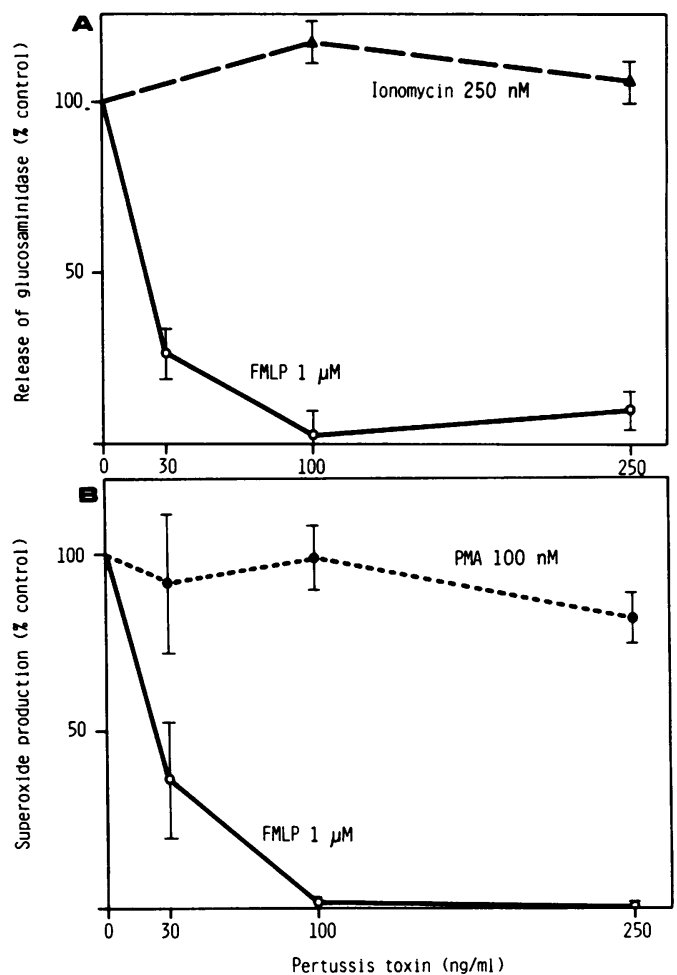

Figure 4. $(A)$ Effect of increasing concentrations of pertussis toxin on glucosaminidase release after 5 min incubation with $1 \mu \mathrm{M}$ FMLP and $250 \mathrm{nM}$ ionomycin in HL-60 cells. Results are expressed as percentage of control cells (cells incubated without pertussis toxin). Control cells released $16 \pm 5$ and $9 \pm 3 \%$ of their total glucosaminidase, respectively, upon stimulation with FMLP or ionomycin (after subtraction of basal values). The results are mean \pm SD of 3-6 determinations. (B) Effect of increasing concentrations of pertussis toxin on initial rates of superoxide production in HL-60 cells in response to $1 \mu \mathrm{M}$ FMLP or $100 \mathrm{nM}$ PMA. The results are expressed as percentage of control cells (cells preincubated without pertussis toxin). Control cells released 6.1 \pm 1.4 and $2.5 \pm 0.5 \mathrm{nmol} \mathrm{O}^{2-} / 10^{6}$ cells/min upon stimulation with PMA and FMLP, respectively. The results are mean \pm standard deviation of 3-6 determinations.

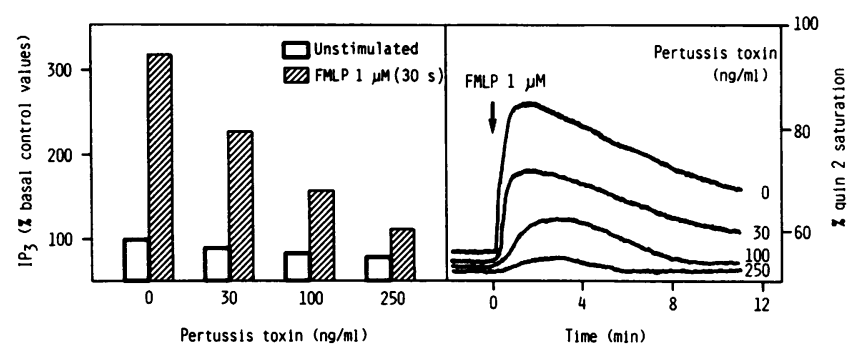

Figure 5. (Left) Effect of increasing concentrations of pertussis toxin on $\mathrm{IP}_{3}$ generation in unstimulated and stimulated (FMLP, $1 \mu \mathrm{M}, 30 \mathrm{~s}$ ) HL-60 cells. Results are expressed as percentage of $\mathrm{IP}_{3}$ values of unstimulated control (preincubation without pertussis toxin) cells and are mean of the triplicates of one experiment, typical for three experiments (for SD see Table II). (Right) Effect of preincubation with increasing concentrations of pertussis toxin on calcium transients in differentiated HL-60 cells, loaded with the fluorescent calcium indicator quin2. All traces were done on the same day and with the same batch of cells as in the left panel; to facilitate comparison they are superimposed. The scale on the right side shows the percentage of maximal changes in Quin 2 flourescence. The traces are typical for three experiments. 
transients monitored on the same day with the same batch of cells as that for the $\mathrm{IP}_{3}$ determinations. $\left[\mathrm{Ca}^{2+}\right]_{\mathrm{i}}$ was lowered in parallel to the effect on $\mathrm{IP}_{3}$ generation. Similar to human neutrophils, calcium transients in calcium-free medium were slightly more affected than in calcium medium (not shown). In Table II, the values of inositol-phosphates and phosphoinositides are given. In addition to its effects on $\mathrm{IP}_{3}$, pertussis toxin inhibited the generation of $I P_{2}$ and $I P_{1}$ due to FMLP. While degranulation and superoxide production are more sensitive to pertussis toxin inhibition than $\mathrm{IP}_{3}$ generation and $\left[\mathrm{Ca}^{2+}\right]_{i}$ rises, the two latter are equally sensitive to toxin treatment of HL-60 cells.

\section{Discussion}

Two aspects of the present study should be emphasized. First, the inhibition of $\mathrm{IP}_{3}$ generation demonstrates directly that pertussis toxin interferes with the FMLP induced activation of phospholipase C. Second, modulation and monitoring of $\mathrm{IP}_{3}$ revealed parallel, although quantitatively different inhibition of $\mathrm{IP}_{3}$ generation, calcium rises and functional responses.

Two cell types that possess specific chemotactic peptide FMLP receptors were used for this investigations: human neutrophils and the differentiated human promyelocytic cell line HL-60, and for both cell types the same pattern of results was observed. Neutrophils possess the advantage of being mature and functional cells, but they have the disadvantage of a short

Table II. Effect of Different Concentrations of Pertussis Toxin on Levels of Inositolphosphates and Phosphoinositides on Unstimulated HL-60 Cells and FMLP-stimulated HL-60 Cells

\begin{tabular}{|c|c|c|c|c|c|}
\hline & & \multicolumn{4}{|c|}{ Pertussis toxin } \\
\hline & & $n g / m l$ & $n g / m l$ & $n g / m l$ & $n g / m l$ \\
\hline & & 0 & 30 & 100 & 250 \\
\hline & Basal & $100 \pm 5$ & $91 \pm 8$ & $85 \pm 6$ & $79 \pm 6$ \\
\hline \multirow[t]{2}{*}{$\mathrm{IP}_{3}$} & Stimulated & $318 \pm 16$ & $228 \pm 3$ & $158 \pm 10$ & $112 \pm 15$ \\
\hline & Basal & $100 \pm 4$ & $76 \pm 4$ & $75 \pm 6$ & $63 \pm 8$ \\
\hline \multirow[t]{2}{*}{$\mathrm{IP}_{\mathbf{2}}$} & Stimulated & $297 \pm 24$ & $241 \pm 70$ & $152 \pm 9$ & $106 \pm 5$ \\
\hline & Basal & $100 \pm 10$ & $100 \pm 4$ & $93 \pm 4$ & $83 \pm 22$ \\
\hline \multirow[t]{2}{*}{$\mathrm{IP}_{1}$} & Stimulated & $139 \pm 9$ & $124 \pm 5$ & $109 \pm 5$ & $90 \pm 13$ \\
\hline & Basal & $100 \pm 9$ & $103 \pm 17$ & $108 \pm 7$ & $88 \pm 11$ \\
\hline \multirow[t]{2}{*}{$\mathrm{PIP}_{2}$} & Stimulated & $100 \pm 5$ & $101 \pm 8$ & $122 \pm 19$ & $106 \pm 9$ \\
\hline & Basal & $100 \pm 13$ & $79 \pm 21$ & $87 \pm 6$ & $66 \pm 6$ \\
\hline \multirow[t]{2}{*}{$\mathrm{PIP}_{1}$} & Stimulated & $101 \pm 8$ & $96 \pm 11$ & $106 \pm 8$ & $88 \pm 6$ \\
\hline & Basal & $100 \pm 1$ & $97 \pm 12$ & $100 \pm 11$ & $90 \pm 14$ \\
\hline PI & Stimulated & $108 \pm 3$ & $100 \pm 6$ & $96 \pm 4$ & $97 \pm 3$ \\
\hline
\end{tabular}

HL-60 cells were cultured in the presence of myo-[2- $\left.{ }^{3} \mathrm{H}\right]$ inositol $(1$ $\mu \mathrm{Ci} / \mathrm{ml})$ for $48 \mathrm{~h}$ and with pertussis toxin at the indicated concentrations for $2 \mathrm{~h} 1 \mu \mathrm{M}$ FMLP (stimulated) or 0.1\% DMSO (basal) was added. The reaction was stopped after $30 \mathrm{~s}$ by adding trichloracetic acid. Inositolphosphates were determined in the supernatant, and phosphoinositides in the precipitate. The values are given as percentage of basal values of control cells (cells incubated without pertussis toxin). Basal values of control cells were $122 \pm 6,140 \pm 6$, and $350 \pm 36$ $\mathrm{dpm}$ for $\mathrm{IP}_{3}, \mathrm{IP}_{2}$, and $\mathrm{IP}_{1}$, respectively, and $671 \pm 64,1,027 \pm 130$, and $1,287 \pm 237 \mathrm{dpm}$ for $\mathrm{PIP}_{2}, \mathrm{PIP}_{1}$, and PI, respectively. Values are mean \pm SD of three determinations. life span, allowing less prolonged labeling periods with $\left[{ }^{3} \mathrm{H}\right]$ inositol $(18 \mathrm{~h})$. Under these conditions, however, the cells exhibit reduced functional responses (3). In addition, large quantities of cells are necessary $\left(12 \times 10^{6}\right.$ cells per determination).

Working with HL-60 cells has the advantage that phosphoinositides can be labeled to isotopic equilibrium ( $48 \mathrm{~h}$ ), such that alterations in label reflect quantitative changes and that less cells $\left(3 \times 10^{6}\right)$ are required for each determination. HL-60 cells remain fully responsive to the various stimuli after the labeling, allowing quantitative comparison between effects on intracellular signals and functional responses. The effect of pertussis toxin on human neutrophils is quite similar to that on HL-60 cells: The FMLP-induced generation of IP3, rises in intracellular calcium, degranulation, and superoxide production are inhibited in a differential concentration dependent manner by pertussis toxin. Calcium changes and functions tested in response to stimuli bypassing the receptor, such as the calcium ionophore ionomycin and the phorbolester PMA, are not inhibited. Thus, our data demonstrate, that the action of pertussis toxin on the chemotactic peptide receptor is proximal to the $\mathrm{IP}_{3}$ rise, and that the regulation of calcium rise, superoxide production, degranulation, and membrane depolarization is distal to the site of inhibition of the toxin.

Elevation of $\left[\mathrm{Ca}^{2+}\right]_{i}$ upon chemotactic peptide activation in neutrophils has been shown to consist of two components: release of $\mathrm{Ca}^{2+}$ from intracellular stores and influx across the plasmalemma from the extracellular medium (1). Although the release of calcium from the stores appears to be mediated by $\mathrm{IP}_{3}(6)$, not much is known about the mechanism that induces calcium influx from the extracellular medium. Our data show parallel inhibition of $\mathrm{Ca}^{2+}$ transients both in the presence and absence of extracellular $\mathrm{Ca}^{2+}$; thus, both release from internal stores and $\mathrm{Ca}^{2+}$ influx are affected by pertussis toxin. The inhibition of $\left[\mathrm{Ca}^{2+}\right]_{\mathrm{i}}$ rises is slightly more pronounced in calcium-free medium, possibly because of a different sensitivity of influx and release to the inhibition by pertussis toxin. Alternatively, phospholipase $\mathrm{C}$ might be more sensitive to inhibition by pertussis toxin in the absence of extracellular calcium.

The correlation of the generation of $\mathrm{IP}_{3}$ with the rise in $\left[\mathrm{Ca}^{2+}\right]_{i}$ measured in intact cells confirms and extends the findings that $\mathrm{IP}_{3}$ mobilizes $\mathrm{Ca}^{2+}$ as assessed in permeabilized neutrophils (6). Although our studies cannot define whether $\mathrm{IP}_{3}$ is involved in calcium influx across the plasmalemma, they do suggest its dependency on a signal created distally to the site of action of pertussis toxin. In another study, in which the quin 2 method has been applied to rabbit neutrophils, it was concluded that pertussis toxin selectively inhibited FMLP-stimulated calcium influx without affecting calcium mobilization (14). Although interspecies differences might account for these conflicting results, they are hard to reconcile with the knowledge that in a variety of other cells, $\mathrm{IP}_{3}$ has been shown to release calcium from intracellular stores $(24,25)$.

In human neutrophils, $\left[\mathrm{Ca}^{2+}\right]_{\mathrm{i}}$ transients and secondary granule releases were less sensitive to pertussis toxin action than superoxide production, depolarization, and primary granule release. In HL-60 cells, comparison of $\mathrm{IP}_{3}$ production with the functional responses and the $\mathrm{Ca}^{2+}$ transients in response to FMLP could be performed under identical experimental conditions. The inhibition of superoxide production and degranulation required lower concentration of pertussis toxin than the inhibition 
of $\mathrm{Ca}^{2+}$ transients and $\mathrm{IP}_{3}$ production. These results indicate a tighter relationship between $\mathrm{IP}_{3}$ and $\left[\mathrm{Ca}^{2+}\right]_{i}$ than $\mathrm{IP}_{3}$ and functional responses. It is known that FMLP receptor occupancy generates another potent stimulatory signal (1), presumably diacylglycerol, which also is produced by phospholipase $\mathrm{C}$. This compound is generally believed to activate protein kinase $\mathrm{C}$ and synergise with $\mathrm{Ca}^{2+}$ to generate functional responses. Although this remains to be shown, the more marked inhibition of functions could be explained by concomitant inhibition of both $\mathrm{IP}_{3}$ and diacylglycerol. In previous studies it was reported that FMLP transiently decreased PIP $_{2}$ levels, assessed after short-term labeling with ${ }^{32} \mathrm{P}_{\mathrm{i}}$, and that pertussis toxin abolished this response. $\mathrm{PIP}_{2}$ can be decreased both by the action of phosphomonoesterase or phospholipase $\mathrm{C}$; the data presented above showing a block of FMLP-induced $\mathrm{IP}_{3}$ production by pertussis toxin now provides evidence that it is indeed the activation of phospholipase $C$ that is impaired by the toxin. In addition, in HL-60 cells labeled to isotopic equilibrium, no significant decrease of $\mathrm{PIP}_{2}$ was observed at $30 \mathrm{~s}$, indicating that resynthesis of phosphoinositides maintains constant $\mathrm{PIP}_{2}$ levels, except for times very early after stimulation as suggested by the ${ }^{32} \mathrm{P}$-labeling experiments $(15,16)$.

The diminished FMLP-induced $\mathrm{IP}_{3}$ rise after preincubation with pertussis toxin does not seem to be a consequence of an accelerated degradation, as it is associated with decreased levels of its degradation products, $\mathrm{IP}_{2}$ and IP. The essentially unchanged levels of membrane phospholipids argue against a diminished concentration of phospholipase $C$ substrate as a cause of the inhibition of $\mathrm{IP}_{3}$ production. A reduction of FMLP binding sites as well as substantial alterations of cAMP levels by pertussis toxin have been excluded by previous studies $(27,28)$. Our data suggest an inhibition of the receptor-mediated phospholipase $\mathrm{C}$ activation by pertussis toxin. What could be the molecular mechanism of this event? A direct effect of pertussis toxin on phospholipase $\mathrm{C}$ is possible, however there is no positive evidence for this. The most likely site of action is the known substrate of pertussis toxin, an $\mathrm{N}$ protein. Several lines of evidence suggest this: (a) N proteins are guanosine-triphosphate (GTP)-dependent proteins, and GTP has been shown to influence the affinity of chemotactic peptide receptors of neutrophils (29) and the stimulus-response coupling in mast cells $(10) ;(b)$ the phospholipase $\mathrm{C}$ of human neutrophil plasma membranes can be activated simply by adding GTP analogues $(11) ;(c)$ the role of GTP-dependent proteins in the signal transduction from the stimulusreceptor complex to the catalytic unit of the adenylate cyclase is well known $(7,8) ;(d)$ an $\mathrm{N}$ protein that can be ADP-ribosylated by pertussis toxin has been demonstrated in neutrophil plasma membranes $(27,28)$; and $(e)$ nicotinamide, an inhibitor of ADPribosyltransferase, attenuates the effect of pertussis toxin on neutrophils (27).

However, this effect of pertussis toxin appears to be a selective event which does not inhibit all calcium mobilizing receptor agonists. Whereas these agonists are inhibited in neutrophils, HL-60 cells, and mast cells, the calcium mobilization by the carbamylcholine receptor of the insulin secreting cell line RINmF5 and the thyrotropin releasing hormone receptor of the pituitary cell line $\mathrm{GH}_{3}$, for instance, are not inhibited even by high doses (up to $1 \mu \mathrm{g} / \mathrm{ml}$ ) of pertussis toxin (Wollheim C. B., and $\mathrm{W}$. Schlegel, unpublished data), although both receptor types are thought to work by phospholipase $\mathrm{C}$ activation, $\mathrm{IP}_{3}$ produc- tion, and consecutive calcium rise, just as the FMLP-receptor of human neutrophils (25), and in beta cells and $\mathrm{GH}_{3}$ cells, an $\mathrm{N}$ protein that can be ADP-ribosylated by pertussis toxin has been demonstrated in the plasma membrane $(30,31)$. Interestingly, in human neutrophils, the concanavalin A-induced rise in $\left[\mathrm{Ca}^{2+}\right]_{\mathrm{i}}$ is not inhibited by pertussis toxin (15). Taken together, these findings suggest the existence of differences in transduction mechanisms between calcium mobilizing agonists.

Since submission of this manuscript, it has been reported that pertussis toxin inhibits exocytosis and $\mathrm{IP}_{3}$ formation in response to FMLP and LTB4 in rabbit neutrophils and HL-60 cells (32-34).

\section{Acknowledgments}

We are most grateful to Antoinette Monod for her skillful and devoted technical assistance, and to Dr. Tullio Pozzan for helpful discussion.

This work was supported by grants $\mathrm{Nr}$. 3.840.083, 3.990.0.84, and 3.246.082 from the Swiss National Foundation.

\section{References}

1. Pozzan, T., P. D. Lew, C. B. Wollheim, and R. Y. Tsien. 1983. Is cytosolic free calcium regulating neutrophil activation? Science (Wash. DC). 221:1413-1415.

2. Lew, P. D., C. B. Wollheim, F. A. Waldvogel, and T. Pozzan. 1984. Modulation of cytosolic-free calcium transients by changes in intracellular calcium-buffering capacity: correlation with exocytosis and $\mathrm{O}_{2}^{-}$production in human neutrophils. J. Cell Biol. 99:1212-1220.

3. Di Virgilio, F., L. M. Vicentini, S. Treves, G. Riz, and T. Pozzan. 1985. Inositol phosphate formation in FMet-Leu-Phe stimulated human neutrophils does not require an increase of the cytosolic free $\mathrm{Ca}^{2+}$ concentration. Biochem. J. 229:361-367.

4. Bradford, P. G., and R. P. Rubin. 1985. Characterization of formylmethionyl-leucyl-phenylalanine stimulation of inositol triphosphate accumulation in rabbit neutrophils. Mol. Pharmacol. 27:74-78.

5. Dougherty, R. W., P. P. Godfrey, P. C. Hoyle, J. W. Putney, Jr., and R. J. Freer. 1984. Secretatogue induced phosphoinositide metabolism in human leukocytes. Biochem. J. 222:307-314.

6. Prentki, M., C. B. Wollheim, and P. D. Lew. 1984. $\mathrm{Ca}^{2+}$ homeostasis in permeabilized human neutrophils: characterization of $\mathrm{Ca}^{2+}$-sequestering pools and the action of Inositol 1,4,5-Trisphosphate. J. Biol. Chem. 259:13777-13782.

7. Rodbell, M. 1980. The role of hormone receptors and GTP-regulatory proteins in membrane transduction. Nature (Lond.). 284:17-22.

8. Gilman, A. G. 1984. G-proteins and dual control of adenylate cyclase. Cell. 36:577-579.

9. Haslam, R. J., and M. M. L. Davidson. 1984. Guanine nucleotides decrease free $\left[\mathrm{Ca}^{2+}\right]$ required for secretion from permeabilized blood platelets. Evidence of a role for a GTP-binding protein in platelet activation. FEBS Fed. Eur. Biochem. Soc. Letts. 174:90-95.

10. Gomperts, B. D. 1983. Involvement of guanine nucleotide-binding protein in the gating of $\mathrm{Ca}^{2+}$ by receptors. Nature (Lond.). 306:64-66.

11. Cockcroft, S., and B. D. Gomperts. 1985. Role of guanine nucleotide binding protein in the activation of polyphosphoinositide phosphodiesterase. Nature (Lond.). 314:934-936.

12. Katada, T., and M. Ui. 1981. Islet activating protein. J. Biol. Chem. 256:8310-8317.

13. Katada, T., G. M. Bokoch, J. K. Northup, M. Ui, and A. G. Gilman. 1984. The inhibitory guanine nucleotide-binding regulatory component of adenylate cyclase. J. Biol. Chem. 259:3568-3577.

14. Molski, T. F. P., P. H. Naccache, M. L. Marsh, J. Kermode, E. L. Becker, and R. I. Sha'afi. 1984. Pertussis toxin inhibits the rise in the intracellular concentration of free calcium that is induced by chemotactic factors in rabbit neutrophils: possible role of the " $G$ proteins" 
in calcium mobilization. Biochem. Biophys. Res. Commun. 124:644650.

15. Verghese, M. W., C. D. Smith, and R. Snyderman. 1985. Potential role for a guanine nucleotide regulatory protein in chemoattractant receptor mediated polyphosphoinositide metabolism, $\mathrm{Ca}^{2+}$ mobilization and cellular responses by leukocytes. Biochem. Biophys. Res. Commun. 127:450-457.

16. Sheifcyk, J., R. Yassin, M. Volpi, T. F. P. Molski, P. H. Nacchache, J. J. Munoz, E. L. Becker, M. B. Feinstein, and R. I. Sha'afi. 1985. Pertussis but not Cholera toxin inhibits the stimulated increase in actin association with the cytoskeleton in rabbit neutrophils: role of the "Gproteins" in stimulus response coupling. Biochem. Biophys. Res. Commun. 126:1174-1181.

17. Boyum, A. 1976. Isolation of lymphocytes, granulocytes and macrophages. Scand. J. Immunol. 5:9-15.

18. Lew, P. D., S. Southwick, T. P. Stossel, J. C. Whitin, E. Simons, and H. J. Cohen. 1981. A variant of chronic granulomatous disease: deficient oxidative metabolism due to a low-affinity NADPH oxidase. N. Engl. J. Med. 305:1329-1333.

19. Dewald, B., U. Bretz, and M. Bagglioni. 1982. Release of gelatinase from a novel secretory compartment of human neutrophils. J. Clin. Invest. 70:518-525.

20. Lew, P. D., and T. P. Stossel. 1981. Effect of calcium on superoxide production by phagocytic vesicles from rabbit alveolar macrophages. $J$. Clin. Invest. 671:1-9.

21. Seligman, B. E., E. K. Gallin, D. L. Martin, W. Shain, and J. I. Gallin. 1980. Interaction of chemotactic factors with human polymorphonuclear leukocytes: studies using a membrane potential-sensitive cyanine dye. J. Membr. Biol. 53:257-272.

22. Jolles, J., K. W. A. Wirtz, P. Schotman, and W. H. Gipsen. 1979. $\mathrm{ACTH}_{1-24}$ affects protein phosphorylation and polyphosphoinositide metabolism in rat brain. Biochem. J. 194:283-291.

23. Berridge, M. J., R. M. C. Dawson, C. P. Downes, J. P. Heslop, and R. F. Irvine. 1983. Changes in the levels of inositol phosphates after agonist dependent hydrolysis of membrane phosphoinositides. Biochem. J. 212:473-482.

24. Berridge, M. J., and R. F. Irvine. 1984. Inositol trisphosphate, a novel second messenger in cellular signal transduction. Nature (Lond.). 312:315-320.
25. Wollheim, C. B., T. J. Biden, P. D. Lew, and W. Schlegel. 1985. Calcium mobilization by inositol 1,4,5-trisphosphate during activation of islet, pituitary and myeloid cells. Cardiovasc. Res. In press.

26. Naccache, P. H., T. F. P. Molski, B. Spinelli, P. Borgeat, and C. N. Abboud. 1984. Development of calcium and secretory responses in the human promyelocytic leukemia cell line HL60. J. Cell. Physiol. 119:241-246.

27. Okajima, F., and M. Ui. 1984. ADP-ribosylation of the specific membrane protein by islet-activating protein, pertussis toxin, associated with inhibition of a chemotactic peptide-induced arachidonate release in neutrophils. J. Biol. Chem. 259:13863-13871.

28. Bokoch, G. M., and A. G. Gilman. 1984. Inhibition if receptormediated release of arachidonic acid by pertussis toxin. Cell. 39:301308.

29. Koo, C., R. J. Lefkowitz, and R. Snyderman. 1983. Guanine nucleotides modulate the binding affinity of the oligopeptide chemoattractant receptor on human polymorphonuclear leukocytes. J. Clin. Invest. 72:748-753.

30. Katada, T., and M. Ui. 1982. Direct modification of the membrane adenylate cyclase system by islet-activating protein due to ADPribosylation of a membrane protein. Proc. Natl. Acad. Sci. USA. 79: 3129-3133.

31. Wojcikiewicz, R. H., P. R. Dobson, L. R. Irons, A. Robinson, and Barry L. Brown. 1984. The relationship between pertussis-toxin induced ADP-ribosylation of a plasma-membrane protein and reversal of muscarinic inhibition of prolaction secretion in $\mathrm{GH}_{3}$ cells. Biochem. J. 224:339-342.

32. Bradford, G. P., and R. P. Rubin. 1985. Pertussis toxin inhibits chemotactic factor-induced phosphilipase $\mathrm{C}$ stimulation and lysosomal enzyme secretion in rabbit neutrophils. FEBS (Fed. Eur. Biochem. Soc.) Letts. 183:317-320.

33. Brandt, S. J., R. W. Dougherty, E. G. Lapetina, and J. E. Niedel. 1985. Pertussis inhibits chemotactic peptide stimulated generation of inositol phosphates and lysosomal enzyme secretion in human leukemic (HL-60) cells. Proc. Natl. Acad. Sci. USA. 82:3277-3280.

34. Becker, E. L., J. C. Kermode, P. H. Naccache, R. Yassin, M. L. Marsh, J. J. Munoz, and R. I. Sha'afi. 1985. The inhibition of neutrophil granule enzyme secretion and chemotaxis by pertussis toxin. J. Cell Biol. 100:1641-1646. 